Vol. 6, No. 1, 2020

\author{
Yuliia Bohdanova
}

\title{
PRINCIPLES OF SPACE PERCEPTION IN NATURE, THEATRICAL SCENOGRAPHY AND ARCHITECTURE
}

\author{
Senior lecturer Department of architectural environment design \\ Lviv Polytechnic National University, Lviv \\ e-mail: Yuliia.L.Bohdanova@1pnu.ua \\ orcid: 0000-0002-9528-0038
}

Received: 05.05.2020 / Revised: 27.05.2020 / Accepted: 27.05.2020

(C) Bohdanova Yu., 2020

https://doi.org/10.23939/as2020.01.135

Abstract. The article focuses on determining particular characteristic patterns of organization and human perception of space, regardless of whether it is anthropogenic, natural, closed or open, or whether it exists literally, or it is depicted on a canvas of theater curtains, or either conveyed through imaginative thinking of an artist. Understanding particular universal patterns of world and space perception ensure the possibility to use them as core principles for various techniques to be implemented by humans in modeling their own space.

Key words: scenography, perspective, accent, perspective reduction, rhythm, dynamic, dominant.

\section{Problem statement}

Nowadays, an ordinary person, regardless of the rhythm of his/her life, resides in at least three different types of space: the natural one, being unaltered by humans, which occupies the largest dimensional space share; the theatrical one or the space of temporary transformations, which is framed within the small local interior or exterior space shares; and the urban architectural one, being anthropogenic and human-changed, which is inbetween the natural and the theatrical ones due to its specific parameters and defined limits. These seemingly quite different spaces make up the micro-world of human existence, no matter what rules govern the way they are created. It is only superficial that everything looks quite clear: space is everything that surrounds us, and time can be observed with the change of day and night. Yet, in-depth consideration of these concepts will immediately bring up new questions. How does a person perceive space and its temporal changes? Is it possible to compress space and time? However, since ancient times humans have been interested in the principles of natural space structure and have tried to reproduce it in their own models. Some of them are worth being paid closer attention as the most characteristic ones.

\section{Analysis of recent research and publications}

Reflections on the laws of creation and the essence of space emerged as early as antiquity. An ancient heritage that has survived to the present days includes the writings of Thales of Miletus, Pythagoras, Democritus, Epicurus, Aristotle, and Ptolemy. The classical understanding of the universe, which has existed and will always remain unchanged, has subsequently turned into the idea of it as evolving. Space and time are extremely common concepts, one can hardly even think of more general ones than these. "Theorists in a wide variety of scientific fields (ranging from cosmology to cultural studies) use space and time as conceptual elements for universal theoretical models designed to provide a conceptual representation of not only physical 
and cosmological realities, but also linguistic, mental and cultural phenomena" (V. Shynkaruk eds., 2002, s. 529). The Renaissance artists (Leonardo da Vinci, Michelangelo Buonarotti, Albrecht Durer) were also interested in the principles of space construction so that it could enable them to realistically convey space in their canvases. The artworks of various periods have also, in their turn, been the subject of research by numerous scholars. Thus, in 1930-32 professor of Lviv Polytechnic Kazimierz Bartel published his most significant paper on the perspective in European art. He was offered to translate it in several languages in his lifetime. Today, the issue of establishing space construction patterns is far from being solved, but it is becoming even more scientifically complex and challenging.

\section{Objective of the article}

The given paper attempts to determine particular characteristic patterns of organization and human perception of space, regardless of whether it is anthropogenic, natural, closed or open, or whether it exists literally, or it is depicted on a canvas of theater curtains, or either conveyed through imaginative thinking of an artist.

\section{Results and discussions}

The most widely accepted way of depicting the depth of space is perspective. The Dictionary of Foreign Words defines the concept as, "a visible scene; a distant view; the appearance of objects or scenes to the eye; the ability to see things" (Perspektyva. Slovnyk inshomovnykh sliv. [online] slovopedia.org.ua Available at: $<\mathrm{http}$ ://slovopedia.org.ua/ 36/53407/245790.html $>$ [Accessed: 19.08.2019]). Interest in perspective is related to the development of optics and various types of art, especially painting. "The laws of perspective were mentioned by the ancient Greek mathematician Euclid in his treatise Optics in the third century BC, whereas the Roman architect Vitruvius referred its practical application in theatrical scenery to the times of Aeschylus (the sixth and fifth centuries BC), but he also wrote about the lost treatises of Anaxagoras and Democritus on the prospective" (Perspektyva. [online] Vikipediya. Vil'na entsyklopediya. Available at: <https:/uk.wikipedia.org/ wiki/Перспектива > [Accessed: 20.08.2019]).

In the natural space people often perceive it through perspective determined by the mountains or trees that surround a river or road. As the objects in vision become more distant and appear further away from the viewer, their size and position in comparison with each other decrease proportionately, creating the illusion of depth. Viewing the images of the Grand Canyon in Colorado (Fig. 1a), one can notice the similarity between and among mountains and houses, between a street and a road (Fig. 1b). Perhaps because nature has always given shelter to a man, it has become a prototype for creating anthropogenic space. The same principle of mountains, but rather buildings located on the opposite sides of the same street, as if rivals or the two opponents, was used by Y. Lysyk in a theatre curtain sketch for Romeo and Juliet ballet performances to symbolize the two worlds of the Capulets and the Montagues feuding families. In an open space where there is no protection, there is a struggle between people. Using perspective enhances understanding of the plot of this life tragedy - it is just as endless as senseless (Fig. 1c).

Visual focus perspective. Visual focus perspective Natural perspective can be enhanced by some visual accent, such as a mountain, for example, which enables to have a better sense of direction and orientation. The principle is widely used in urban architectural design. The streets end with reference points associated with public objects that are always individual in nature and contrast with overall surroundings. Thus, in the perspective of Ruska Street in Lviv, which has existed since the fourteenth century, one can see the church of the monastery of the Barefoot Carmelites, the construction of which began in 1634. In the past it was common for sacred sites to shape the city street perspective. At the end of the nineteenth century, with the increasing pace of construction, this function was taken over by hotels, theaters, train stations, universities, banks, houses of justice, and other buildings. The theatre curtain painting for The Nutcracker ballet created by Y. Lysyk revealed the use of a visual accent - a Christmas tree, which introduced the audience to the idea of events taking place during the Christmas holidays. It is under the Christmas tree that, according to E. Hoffman's fairy tale, toys come to life, and the Nutcracker, having turned into a handsome prince, enters into a deadly fight with the Mouse King and defeats him. The Christmas tree scene in this story is the place where the action develops which is the performance reference point. 

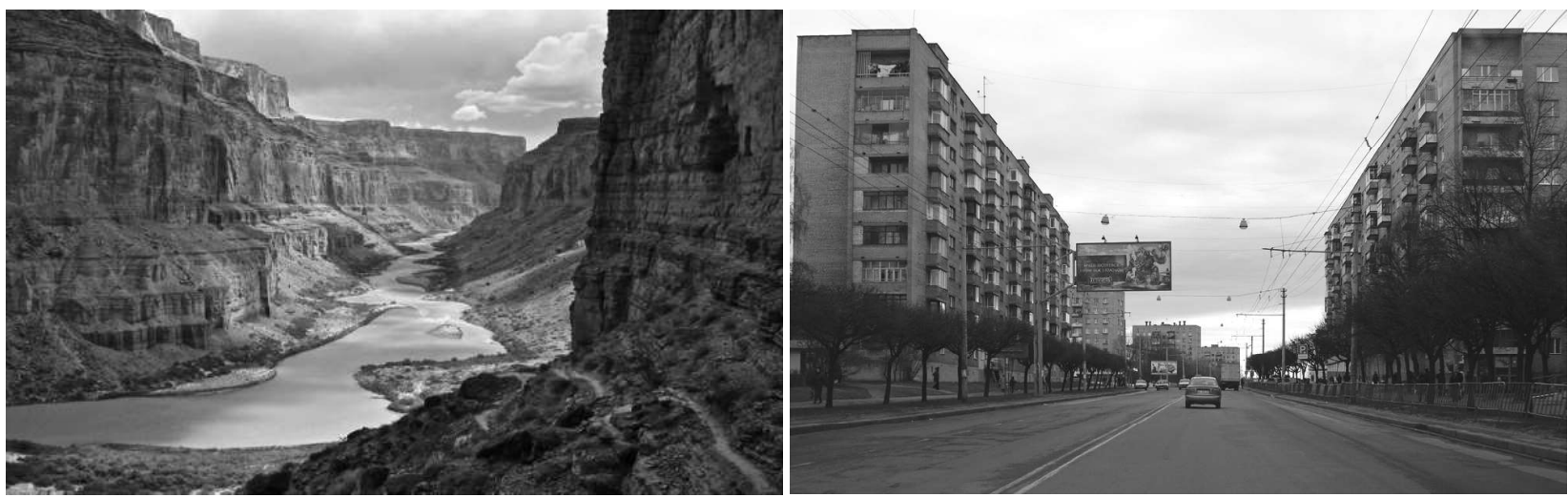

b

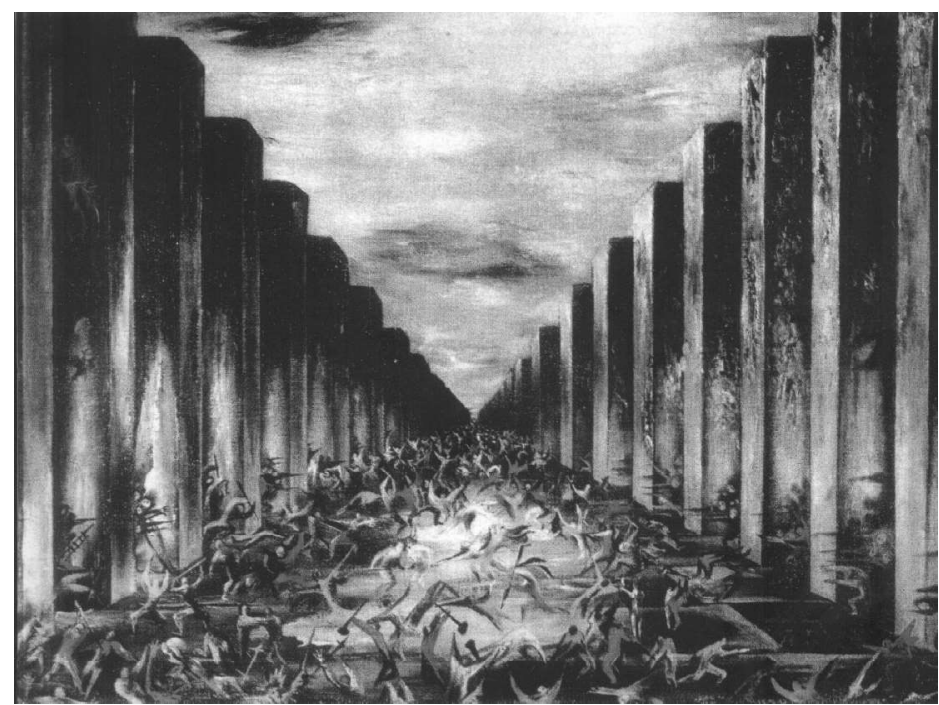

Fig. 1. Perspective:

a - Natural space (the Grand Canyon in Colorado) (Tsikave pro natsional'nyy park Hrand-Kan'yon. [online]); b - Urban architectural space (Liubinska street, Lviv) (Zhytlova zabudova vulytsi Lyubins'koyi. [online]); $\mathrm{c}$ - Theatrical space (Sketch for the theatre curtain of Romeo and Juliet ballet performances. Y. Lysyk)

(V. Proskuryakov, Klymko Z. O., Zinchenko red., 2005, s. 1)

Vertical perspective. If a person looks upwards, he perceives the surrounding vertical objects, such as trees, as if they were even higher than they actually are (Fig. 2a). "In 1771, the French architect JacquesFrançois Blondel stated that the Gothic vaults came from natural specimens being a tree shape imitation with columns as tree trunks and the vault ribs as branches extending upwards" (Basegoda-i-Noyel' Zhan, 2007, p. 6). Thus, the Gothic temple's architecture represented the architects' attempts to reveal the mystery and majesty of God. The cathedral space incomparable to a man, its towers and vaults sharp verticals, the sculptures coordinated and harmonized with dynamic architectural rhythms, the multicolored radiance of stained glass windows exerted strong emotional influence on the religious people (Fig. 2b). In contemplating the stained glass, a man disassociates himself from the material, bodily, the human world and falls into the immanent, spiritual, divine one. Creating images in a vertical perspective is a common technique for monumental painting wherein it is often used to project height onto a plane and enhance the expressiveness of the created architectural objects to be perceived at a close range. The upward perspective reduction was used by Y. Lysyk in the theatre curtain painting for R. Wagner's Lohengrin Romantic Opera to emphasize the tragedy of the main character's life mission (Fig. 2c). The story is based on folk legends about a knight sailing in a boat with a swan. He appears when a woman, abandoned by everyone, is threatened with mortal danger. The knight sets her free from her enemies and marries her. They live happily ever after. Although unexpectedly, the knight disappears as 
mysteriously as he appeared. R. Wagner created an original concept that revealed relevant philosophical and moral problems of those times. Lohengrin's tragedy emerges to be lost in infinity and, according to Wagner, "has its deep roots in the principles of modern life".

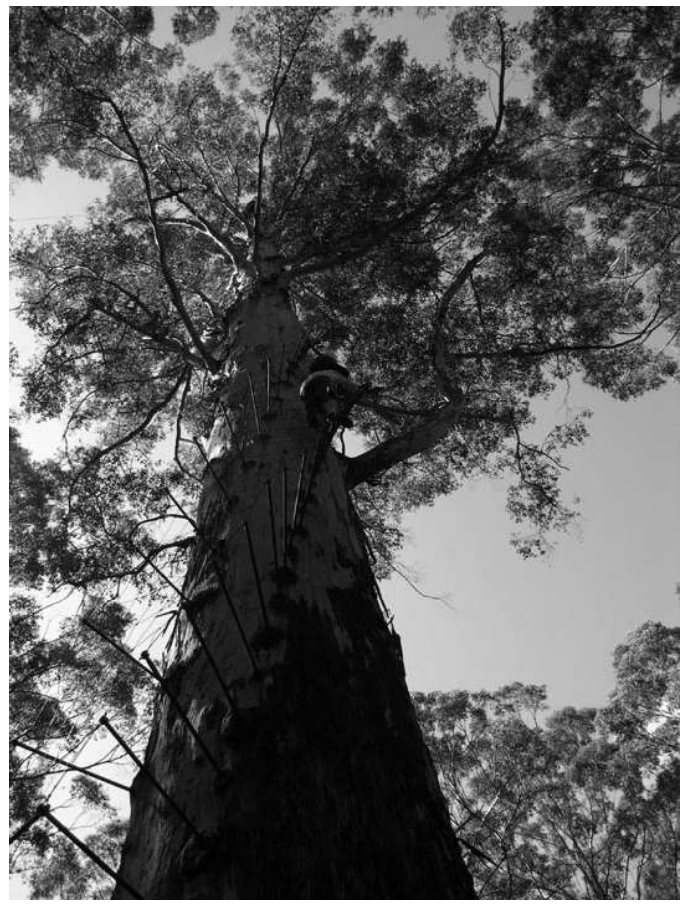

a

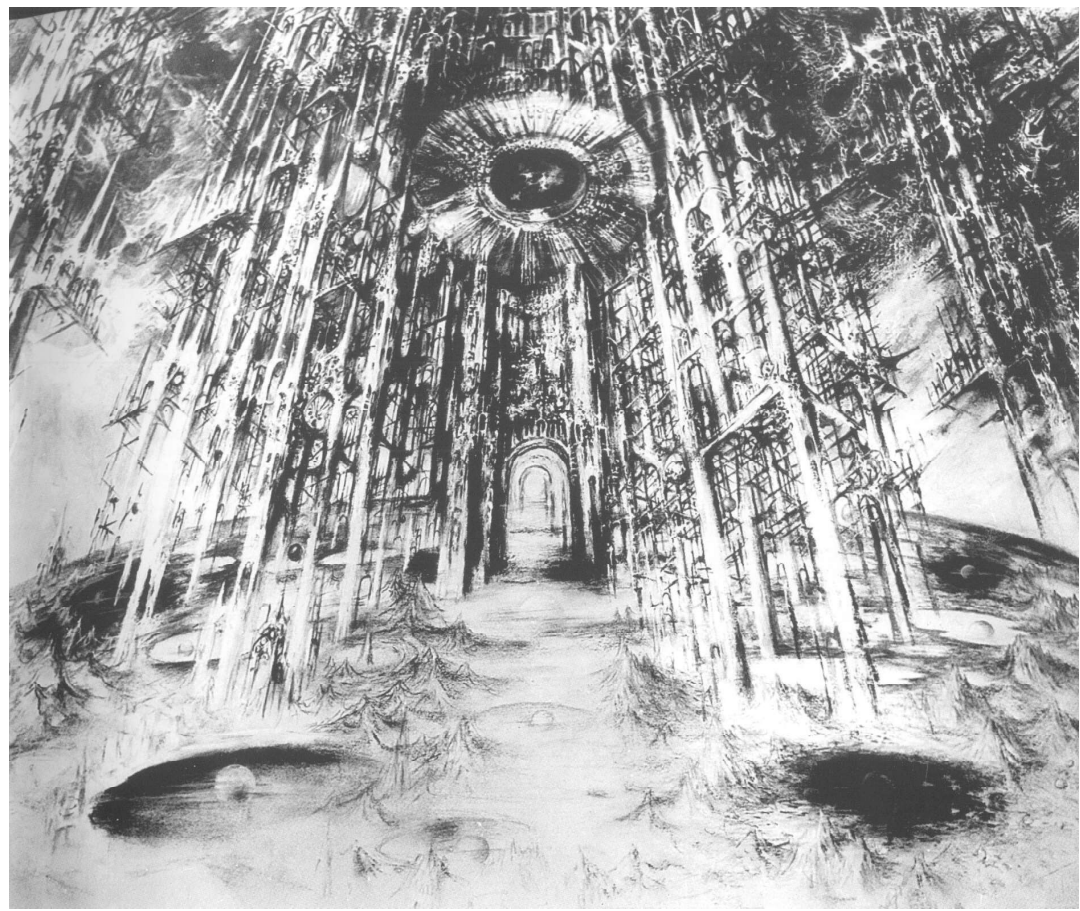

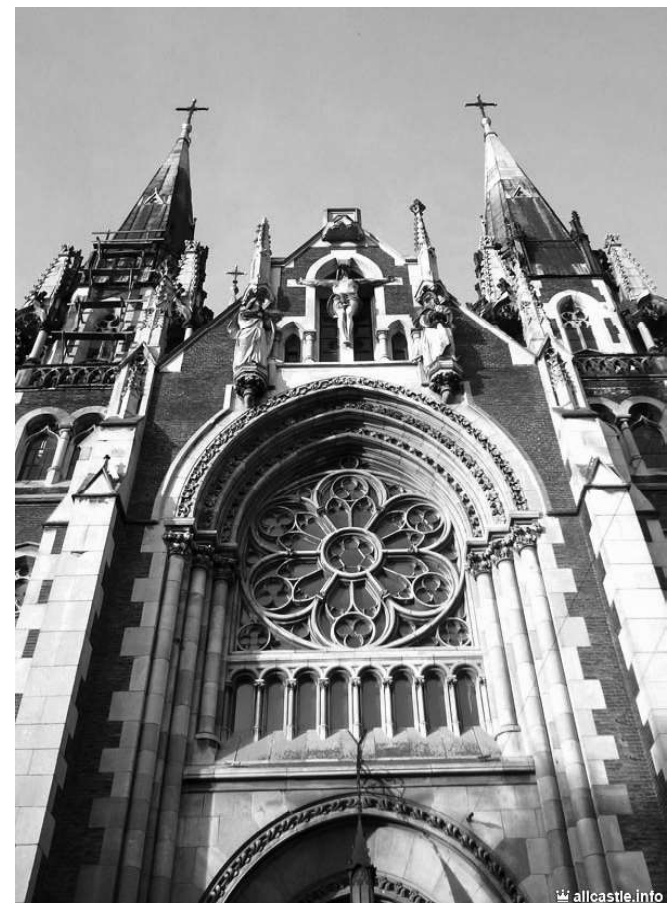

Fig. 2. Vertical perspective:

a - Natural space (tree image in upward foreshortening) (Eucalyptus diversicolor. Evkalipt riznobarvnyy. 2005. [online]); b - Urban architectural space (Church of St. Elizabeth, Lviv) (Kostel Svyatoy El'zhbety (Ol'gi i Yelizavety). [online]); c - Theatrical space

(Lohengrin's performance scenery sketch. Y. Lysyk) (V. Proskuryakov, Klymko Z. O., Zinchenko red., 2005, s. 11) 
Rhythmicity (repetition). Nature is frequently observed to bear plurality consisting of identical or similar elements. For example, an oak grove despite the repetition of the same kind of tree - the oak, manifests the sole integrity of trees - the grove. Urban architecture has its integral formations: facades of historic buildings limit market square spaces and buildings of the second half of the twentieth century created new residential areas. The theatre curtain painting created by Y. Lysyk for The Golden Crown opera performance, which is based on the story Zakhar Berkut by I. Franko, depicted a large number of people similar in appearance. It symbolized the unity of all people. Moral qualities as courage, heroism, overwhelming love, brought them to unite and fight against the enslavement threat of their Motherland by the Mongols.

Centricity. Although nature is believed not to be abundant in perfect shapes, God, as the creator of the world, has often been depicted with compasses. Sometimes, in a rather non-literal form, one can notice a natural circle in the shape of a lake, or the tops of trees around, or something else ... Just in the same way as people have the vision of trees in nature, they perceive urban space with high-rise objects. Humans have always wanted to create something ideal. Therefore, buildings and structures have been erected in accordance with exemplary geometrical shapes, such as, for example, a circle (rotunda temple, gazebo-rotunda). Each historic city has a centered (radially concentric) pattern of development, which is visible from the Master Plan. The technique of centricity was used by Y. Lysyk in the theatre curtain painting for Spartacus ballet performances, which rendered the vortex of human life and its dynamics. The circle image in the stage scenery painting for Medea opera indicated a closed space and the fatum impossible to escape from. An unrequited love for Jason, helping to acquire the golden fleece by betraying the family, revenge on the unfaithful husband, murdering her own children are the thoughts that devastated the main character throughout the performance.

Interpenetration (blending) of the natural and anthropogenic spaces. Humans are constantly invading nature and capturing more and more territories. However, today they are trying to build housing that is as much integrated into the natural environment as possible with distant locations to noisy areas of big cities. Although densely developed, it offers green spaces that always have a positive impact on the lives of urban residents. It is in this way that the natural and anthropogenic spaces tend to blend. Stage scenery paintings in The Fern Flower folk opera were created by Y. Lysyk to show that throughout their history Ukrainian people were inextricably tied up with nature in their rituals. The opera is literary based on the works of Nikolai Gogol and is widely distinguished for its scenery with numerous symbolic paintings, which represent supernatural fictional characters and legends penetrating and complementing human stories.

Futurist (sculpture) dominants. Nature has created numerous dominants that appear distinctive and contrastive with the environment, which is proved by, for example, Meteor Rocks in Greece formed over 60 million years ago (Fig. 3a). The effects of water, wind and temperature changes caused massive, pillarshaped stone formations to emerge rising up to $600 \mathrm{~m}$ above the sea level (Meteory - unikal'nyy monastyrs'kyy kompleks u Hretsiyi. [online]). The dominant is always inherent in both natural and urban spaces. It is always a landmark or an identifiable public building indicative of performing a number of predetermined functions. For example, Arena Lviv Stadium was built for Euro 2012 events (Fig. 3b). It has a capacity of 33-35 thousand people and nowadays it is used to hold football tournaments, to host concert performances and other cultural events (Stadion "Arena Lvov".. [online]). Presently, this facility is dominant in the newly designed city residential area. Creation of the World ballet composed by Andrey Petrov is well-known for its abundant stage scenery. It is an entertaining choreographic story of how God created the Earth. One of the painted curtains depicts Cerberus guard dog as the dominant of The Third Circle of Hell by Dante. Y. Lysyk represented it as a symbol of incomprehensible but supreme and powerful fear seemingly hanging over humans in the stage space (Fig. 3c).

Dynamics. The movement of natural forces, such as wind, waves have always been particularly useful and beneficial for human activity in terms of its application. Mills are the most common example in history. However, the benefits of natural forces were not the only issues that awakened curiosity. Natural dynamics have been intensively transferred into urban space. These are first and foremost road traffic and urban lights. Night city streets host theatrical events accompanied by fireworks, illuminations, light, and torch theatre shows. Any movement in space in principle triggers space dynamics, which is opposite to static state, that is, peace. 
However, dynamics are possible to be projected onto a horizontal flat surface. Yellow and red accent colors in addition to numerous compositional diagonals were used by Y. Lysyk in the Tannhauser opera stage scenery sketch to reveal internal contradictions, torments, and distress which overburden the main character's soul. He seemed to fail to muddle through the maelstrom of emotions he had been led to by life experiences. Struggling between sacred and profane love, he appeared to have been lost in his doubts and unable to make a lifechanging decision who to give his love to, whether to Venus, the goddess, or to the girl Elizabeth. The artwork contrasts two different worlds fighting for Tannhauser's soul, being the world of strict moral obligation and the world of sensual delights in the fascinating kingdom of Venus.

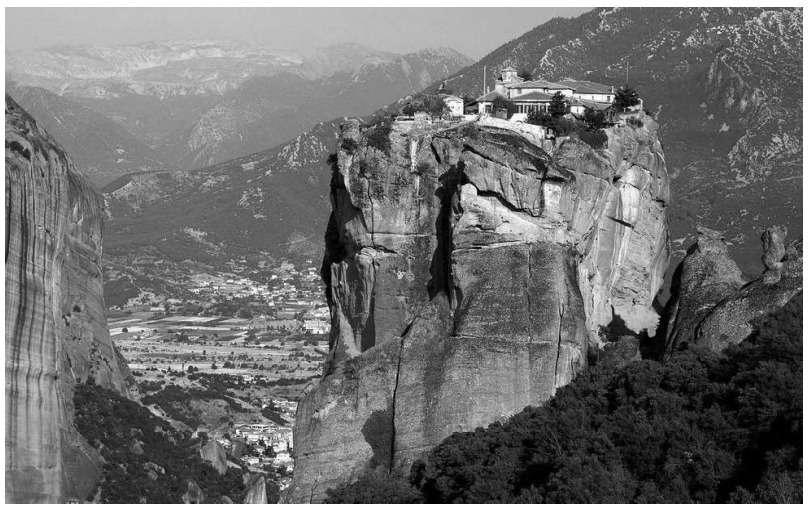

a

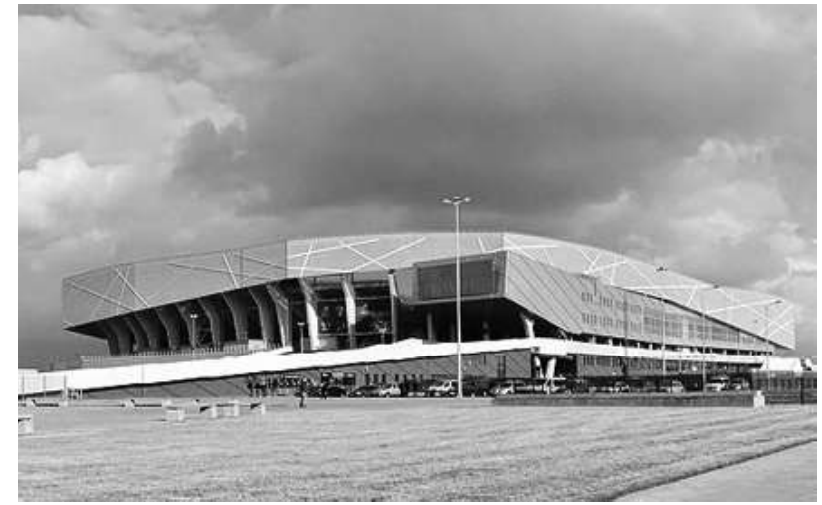

b

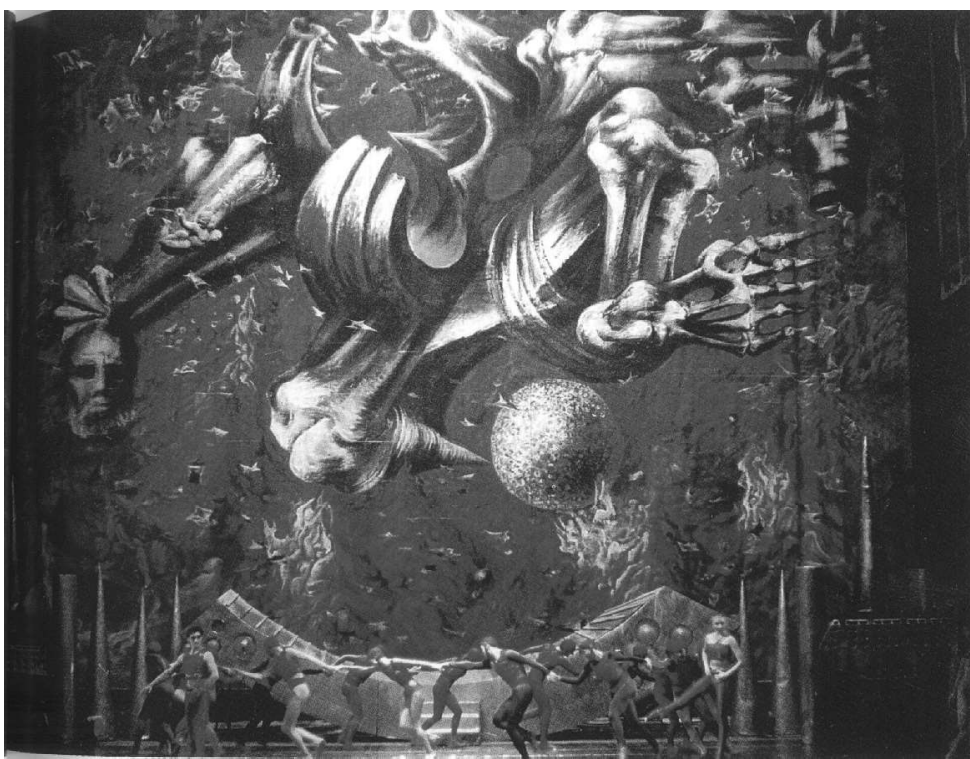

c

Fig. 3. Futurist (sculpture) dominants a - Natural space (Meteor Rocks in Greece)

(Meteory - unikal'nyy monastyrs'kyy kompleks u Hretsiyi. [online]);

b - Urban architectural space (Arena Lviv Stadium, Lviv) (Stadion "Arena Lvov". [online]) $\mathrm{c}$ - Theatrical space (Theatre curtain for Creation of the World ballet performance.

The Third Circle of Hell. Y. Lysyk) (V. Proskuryakov, Klymko Z. O., Zinchenko red., 2005, s. 31)

\section{Conclusions}

Understanding particular universal patterns of world and space perception ensure the possibility to use them as core principles for various techniques to be implemented by humans in modeling their own space. 
Natural observations are often embodied and reproduced in urban architectural design. In scenographic art, where the artists have to compress space and time in accordance with the limits of stage size and performance length, such techniques appear instrumental in projecting space onto the flat surfaces of theatre curtains or designing a stage layout. Urban space parameters are considerably more sizeable than those of the theatre. Nonetheless, the city space can become a theatrical performance one, provided the above techniques are appropriately understood appropriately and skillfully applied.

\section{References}

V. Shynkaruk eds. 2002. Filosofs'kyy entsyklopedychnyy slovnyk. Kyyiv: Abrys, s. 529.

Perspektyva. Slovnyk inshomovnykh sliv. [online] slovopedia.org.ua Available at: <http://slovopedia.org.ua/36/53407/245790.html> [Accessed: 19.08.2019].

Perspektyva. [online] Vikipediya. Vil'na entsyklopediya. Available at: <https://uk.wikipedia.org/wiki/Перспектива > [Accessed: 20.08.2019].

Tsikave pro natsional'nyy park Hrand-Kan'yon. [online] cikavo-znaty.com Available at: <https://cikavo-znaty.com/753ckave-pro-naconalniy-park-grand-kanyon-html/> [Accessed: 21.08.2019].

Zhytlova zabudova vulytsi Lyubins'koyi. [online] Vikipediya. Vil'na entsyklopediya. Available at: <https://uk.wikipedia.org/ wiki/Вулиця_Любінська\#/media/Файл:WP_Любинская.jpg> [Accessed: 1.03.2020].

V. Proskuryakov, Klymko Z.O., Zinchenko red., 2005. Yevhen Lysyk: Bibliohrafischnyy pokazhchyk. L'viv: Sribne slovo. s. $1,11,31$.

Basegoda-i-Noyel' Zhan. 2007. Gaudi. Vse raboty. Perevod S. Samarinoy. Sant Liuis. Menorka:Triangle Postals. p. 6.

Eucalyptus diversicolor. Evkalipt riznobarvnyy. 2005. [online] Vikipediya. Vil'na entsyklopediya. Available at: $<$ https://uk.wikipedia.org/wiki/Eucalyptus_diversicolor\#/media/ File: ClimbingThe GloucesterTree_2005_SeanMcClean.jpg > [Accessed: 1.03.2020].

Kostel Svyatoy El'zhbety (Ol'gi i Yelizavety). [online] allcastle.info Available at: <https://allcastle.info/europe/ukraine/034 $>$ [Accessed: 1.03.2020].

Meteory - unikal'nyy monastyrs'kyy kompleks u Hretsiyi. [online] myplanet.com.ua Available at: <http://myplanet. com.ua/?p=8365 > [Accessed: 1.03.2020].

Stadion "Arena Lvov". [online] planetofhotels.com Available at: <https://planetofhotels.com/ukraina/lvov/stadion-arenalvov> [Accessed: 1.03.2020].

\section{Юлія Богданова}

Ст. викл. кафедри дизайну архітектурного середовища,

Національний університет "Львівська політехніка", Львів

e-mail: Yuliia.L.Bohdanova@lpnu.ua

orcid: 0000-0002-9528-0038

\section{ЗАКОНОМІРНОСТІ СПРИЙНЯТТЯ ПРОСТОРУ В ПРИРОДІ, ТЕАТРАЛЬНІЙ СЦЕНОГРАФІЇ ТА АРХІТЕКТУРІ}

\footnotetext{
Анотація. Сьогодні звичайна людина, не залежно від ритму свого життя, перебуває шонайменше у трьох різних середовищах. Природне (не змінене людиною) - займає найбільший за вимірами простір. Театральне чи театралізоване (середовище перевтілень на короткий термін часу) - зосереджене в локальних, невеликих за розмірами просторах інтер 'єрного чи екстер'єрного характеру. Архітектурне - міське (антропогенне - повністю змінене людиною), що, зважаючи на свої параметри та окреслені межі, займає середню позицію між природним та театральним. Ці, $з$ першого погляду, дуже відмінні середовища є мікросвітом існування людства, не залежно від того, за якими правилами вони творяться. Проте, напевно, ще з давніх часів людина иікавилася закономірностями організації природного середовища і намагалася відтворити його у власних моделях. Хочеться звернути увагу лише на деякі з них, що є найбільш характерними: перспектива, з візуальним акцентом, та вертикальна ритмічність (повторюваність), иентричність, взаємопроникнення (перемішування) природного та антропогенного середовища, футуристичні (скульптурні) домінанти, динаміка.

Роздуми щодо закономірностей творення і сутності простору почалися ще в античності. Класичне розуміння Всесвіту як такого, що існував та існуватиме незмінним завжди, згодом змінилося на уявлення, в якому він еволюиіонує в часі. Простір і час - че гранично загальні поняття, більи загальні важко навіть уявити. Законами побудови простору
} 
цікавились художники доби Відродження, аби отримати змогу реалістично передавати середовище на свої полотнах. Сьогодні питання пошуків закономірностей побудови простору не тільки не являсться вичерпаним, а набуває дедалі складнішого характеру дослідень.

Метою публікачії є намагання визначити деякі характерні закономірності організаиії та сприйняття людиною середовища, що існують незалежно від того, чи простір є антропогенним, чи природнім, чи замкнутим, чи відкритим, чи існує буквально, чи зображений на полотні театральної завіси, переданий завдяки образному мисленню художника.

Розуміння деяких вище перелічених універсальних закономірностей сприйняття світу і простору дають можливість людині, відтворюючи їх за допомогою різних прийомів, моделювати своє власне середовище. Проєктуючи будинки, вулииі і иілі міста архітектори часто копіюють і переносять в свої твори те, що вони побачили у природі. У сценографічному мистечтві, де художник має стиснути простір та час відповідно до розмірів сиени та довжини спектаклю, иі прийоми використовуються для зображенні простору на пласких поверхнях завіс, або при побудові макету сиени. Середовище міста, незважаючи на свої значно більші параметри ніж театр, за умови розуміння та грамотного застосування иих прийомів, саме може стати простором театралізованої дії.

Ключові слова: сиенографія, перспектива, акиент, перспективне скорочення, ритм, динаміка, домінанта. 